\title{
ANALISIS METODE CONNECTED VERTICES CLUSTERING AND STAR TOPOLOGY PADA SERANGAN GEOMETRI TERHADAP WATERMARKING OBJEK 3D
}

\author{
Oriza Intani ${ }^{1}$, Bambang Hidayat ${ }^{2}$, Suryo Adhi Wibowo ${ }^{3}$ \\ 1,2,3Fakultas Teknik Elektro, Universitas Telkom \\ 10riza.intani@gmail.com, ${ }^{2}$ bhidayat@telkomuniversity.ac.id,${ }^{3}$ suryoadhiwibowo@ telkomuniversity.com
}

\begin{abstract}
Abstrak
Dalam usaha untuk melindungi hak cipta dan keaslian dari suatu objek tiga dimensi, diperlukan sebuah algoritma untuk menyisipkan informasi rahasia yang tidak nampak oleh indera penglihatan manusia namun dapat dideteksi dengan menggunakan suatu media, misalnya komputer. Oleh karena itu watermark menjadi sebuah solusi terbaik untuk permasalahan tersebut. Metode yang digunakan untuk menanamkan watermark ke dalam objek 3 dimensi adalah metode connected vertices clustering and topology star, dimana sebuah objek 3 dimensi dibagi-bagi menjadi beberapa topologi star berdasarkan vertex-vertex-nya yang saling terhubung. Dari topologi star ini dipilih edge-edge untuk disisipi informasi watermark dan dengan menggunakan sebuah PN sequensial dipilih edge yang vertex-nya disisipi oleh watermark. Hasil yang diperoleh dari simulasi sitem watermarking ini adalah didapat sebuah skema penanaman watermark dengan kualitas imperceptibility yang baik karena memiliki nilai BER dan VER yang mendekati 0 serta nilai SNR yang besar. Selain itu watermark dapat diekstrak dengan sangat baik setelah diberi serangan rotasi, scaling, translasi, serta kombinasi serangan scaling dan translasi dengan nilai BER O. Skema ini tidak robust terhadap serangan cropping.
\end{abstract}

Kata Kunci: object 3D, watermarking, star topology, connected vertices clustering

\section{Abstract}

In an effort to protect the copyright of a three-dimensional object, it is needed an algorithm to insert the secret information that is not visible by the human sight, but can be detected by a medium, such as computer. Therefore watermark is a best solution for the problem above. The method that is used to embed a watermark into a 3-dimensional object is a method of connected vertices clustering and star topology, where the three dimensional object is divided into several star topology based on the interconnected vertices. There are some edges that are selected by PN sequence to be embedded by watermark. Watermark is embedded in the vertices of the selected edges. The results of the simulations is obtained a good imperceptibility because the value of MSE and VER is close to 0 and the value of SNR is big enough. Beside it, the watermark can be extracted with a very good after being attacked by rotation, scaling, translation, and the combination of scaling and translation with the BER value is 0 . This scheme is not robust against cropping attack.

Keywords: 3D object, watermarking, star topology, connected vertices clustering

\section{Pendahuluan}

Perkembangan dunia multimedia kini menjadi semakin pesat. Untuk representasi citra sendiri tidak cukup hanya pada citra 2 dimensi saja. Kini objek 3 dimensi pun sudah banyak kita jumpai dalam berbagai aplikasi multimedia, mulai dari perfilman, games, citra medis bahkan logo-logo suatu instansi. Indera penglihatan manusia menuntut untuk mendapatkan representasi suatu citra yang semirip mungkin dengan benda aslinya, untuk itulah saat ini objek 3 dimensi dirasa dapat memberikan solusi untuk memanjakan penglihatan mata manusia dengan gambaran semirip mungkin dengan objek aslinya. Seiring dengan perkembangan internet, penyebaran objek 3 dimensi sendiri menjadi tidak terbatas karena setiap orang sudah dapat menggunakan objek-objek 3 dimensi untuk kepentingan pribadi mereka. Mereka bebas mengunduh objek 3 dimensi dari jaringan internet. Hal ini tentu saja menciptakan suatu masalah dalam hal kepemilikan objek 3 dimensi tersebut. Untuk itulah diperlukan sebuah teknologi untuk dapat melindungi hak milik dari objek 3 dimensi tersebut.

Salah satu teknik untuk melindungi hak milik dari suatu data adalah dengan watermarking. Watermarking sendiri adalah sebuah teknik untuk menyisipkan sebuah informasi ke dalam suatu data tanpa merusak data tersebut. Informasi yang ditanam di dalam sebuah data dapat diekstrak sewaktu-waktu bila diperlukan untuk membuktikan kepemilikan dari data yang disisipi watermark tersebut. Atas latar belakang inilah, kemudian penulis melakukan penelitian tentang watermarking pada objek 3 dimensi. 


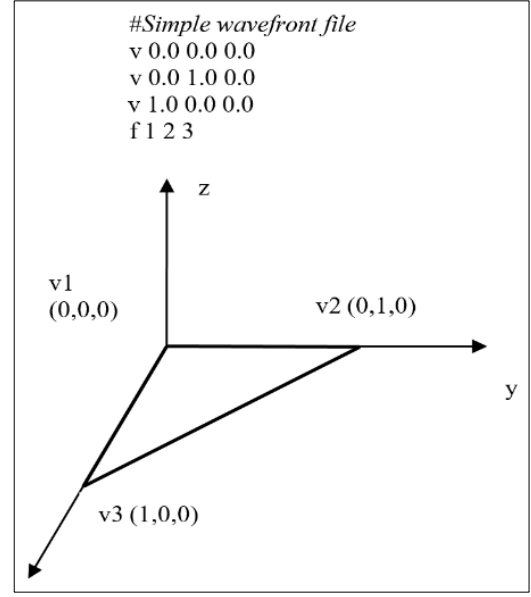

Gambar 1. Segitiga Sederhana

Saat ini watermarking telah banyak digunakan pada citra 2 dimensi, sedangkan untuk objek 3 dimensi masih jarang ditemui skema watermarking yang kokoh terhadap serangan. Penelitian tentang watermarking pada objek 3 dimensi yang sudah pernah ada sebelumnya menggunakan metode transformasi wavelet pada domain frekuensi dan metoda fuzzy pada domain spasial. Dari penelitian yang telah dilakukan tersebut didapat hasil SNR untuk serangan rotasi pada objek 3 dimensi dengan metode haar wavelet adalah 310 dan untuk metoda fuzzy logic adalah 400. Selain itu penelitian yang sejenis juga pernah dilakukan dengan menggunakan metode lazy wavelet. Dari penelitian dengan menggunakan lazy wavelet ini didapat nilai MSE yang mendekati nol dan watermark dapat diekstrak kembali pada objek tiga dimensi yang telah diberi serangan geometris. Didalam penelitian ini penulis akan menggunakan metode connected vertices clustering and star topology yang bekerja pada domain spasial. Hal ini dilakukan dengan tujuan untuk mendapatkan skema watermarking yang kokoh namun dengan proses yang lebih sederhana.

\section{Persamaan Matematika}

\subsection{Objek Tiga Dimensi [2]}

Objek tiga dimensi adalah sebuah citra untuk merepresentasikan suatu objek yang memiliki panjang, lebar dan tinggi. Seperti suatu benda asli, objek tiga dimensi pun harus dapat dilihat dari berbagai sisi. Untuk merepresentasikan bentuk objek tiga dimensi biasanya digunakan triangular meshes, dimana sebuah objek tiga dimensi terbentuk dari segitiga-segitiga atau biasa disebut dengan face.

Salah satu teknologi representasi objek tiga dimensi yang menggunakan face sebagai penyusunnya adalah file dengan format *.obj. File *.obj atau biasa dikenal dengan teknologi wavefront yang digunakan pada aplikasi Wavefront's Advanced Visualizer untuk membuat sebuah objek tersusun atas garis, poligon, kurva bentuk bebas, dan surface namun tidak mengandung komponen warna. File *.obj ini akan disimpan dalam format ASCII. Garis dan poligon dideskripsikan dalam poin-poin, sementara kurva dan surface didefinisikan dengan titik-kontrol dan deskripsi informasi lainnya tergantung pada jenis kurvanya. File *.obj mengandung face yang biasanya dibentuk dalam triangle mesh atau polygonal face. Sebagai contoh dibawah ini merupakan format file * obj pembentuk segitiga sederhana. Segitiga sederhana tersebut dapat dilihat pada Gambar 1.

Pada matriks sederhana pembentuk segitiga di atas keyword $v$ merepresentasikan vertex atau titik, sedangkan keywordf merepresentasikan face.

\subsection{Watermarking $[3,4,5]$}

Watermarking adalah istilah teknik untuk menanamkan dan menyembunyikan informasi rahasia ke dalam suatu file. Dengan seiringnya waktu, teknik ini juga memungkinkan untuk memeriksa apakah suatu file telah disisipi sebuah informasi rahasia atau tidak dan untuk mengetahui informasi apa yang telah disisipkan ke dalam sebuah file. Penanaman informasi memiliki tujuan untuk melindungi file dari editing oleh pihak yang tidak diinginkan. Selain itu watermarking juga dapat digunakan untuk melindungi hak cipta pemilik file dengan cara menyisipkan informasi tentang pemilik file ke dalam file itu sendiri. Informasi rahasia dalam pengertian watermarking merujuk kepada informasi yang tidak terlihat secara kasat mata, namun dapat diketahui keberadaan dan informasinya melalui sebuah media, misalnya komputer.

Watermark yang ideal tidak boleh mengganggu tujuan dari data, dalam makalah ini adalah objek tiga dimensi. Untuk itu maka algoritma watermarking yang bagus adalah yang tidak menampakan watermark pada host-nya. Untuk saat ini algoritma watermarking untuk objek tiga dimensi masih sedikit karena teknik watermarking untuk objek tiga dimensi memiliki kesulitan, di antaranya:

a. Bila dibandingkan dengan gambar dua dimensi, hanya ada sejumlah kecil data (misal vertex) yang tersedia untuk disisipi watermark.

b. Belum ada transformasi yang kuat yang dapat digunakan untuk menanamkan watermark ke dalam objek tiga dimensi.

Ada dua kelas utama dari aplikasi watermaking, yaitu:

a. Memeriksa integritas: tujuannya adalah untuk dapat mendeteksi bahwa file telah dirusak dengan memasukkan watermark rapuh yang akan hilang jika dokumen dirubah, dan mungkin dapat diketahui bagian dari dokumen yang diubah.

b. Otentikasi: tujuannya adalah untuk dapat mengatakan bahwa suatu dokumen yang berasal dari sumber tertentu telah dimanipulasi dan dirusak dalam upaya untuk menghapus watermark. 


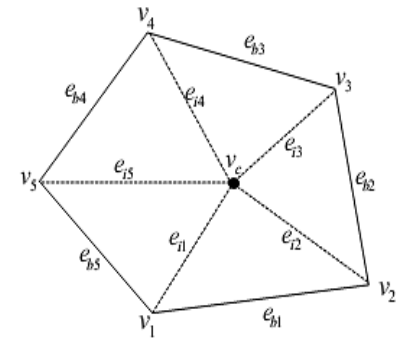

Gambar 2. Topologi Star

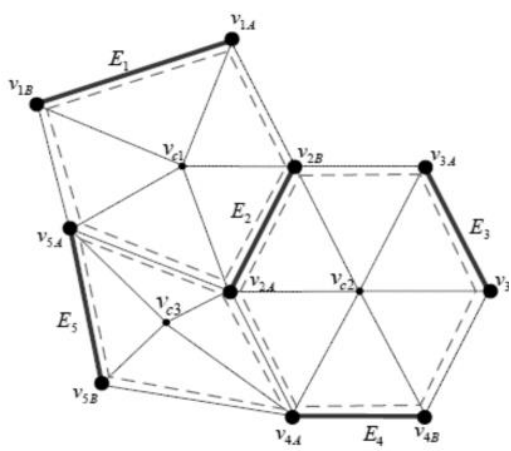

Gambar 3. Kandidat Edge

Aspek penting dalam watermarking, di antaranya:

a. Validasi: watermark dapat diekstrak sepenuhnya dari objek tiga dimensi yang tidak diberi serangan.

b. Kapasitas: jumlah informasi yang dapat disembunyikan dalam suatu file.

c. Visibilitas: distorsi gambar dan degradasi penglihatan karena penyisipan watermark, dan diharapkan bahwa watermark menjadi tak terlihat.

d. Robustness: kemampuan untuk memulihkan watermark bahkan setelah gambar telah dimanipulasi dan diubah. lain:

Tiga metode ekstraksi watermarking, antara

a. Blind: watermark dapat diekstraksi dari objek yang telah disisipi watermark dan tidak memerlukan informasi lain.

b. Semi-blind: seseorang dapat memeriksa apakah watermark tertanam atau tidak dalam sebuah objek.

c. Non-blind: watermark dapat diekstraksi dengan menggunakan objek asli dari objek yang telah disisipi watermark.

\subsection{Topologi Star [1]}

Sebuah model tiga dimensi permukaannya sering diwakili oleh segitiga atau biasa kita sebut dengan triangular mesh. Dalam triangular mesh terdapat sisi-sisi yang menbentuk segitiga. Segitigasegitiga ini dikumpulkan membentuk sebuah topologi star (Gambar 2). Sisi atau yang lebih lanjut akan kita sebut sebagai edge yang merupakan edge bersama antara dua segitiga disebut sebagai edge interior, sedangkan edge yang milik segitiga tunggal disebut edge batas.
Sebuah loop tertutup dibentuk dengan menghubungkan edge batas tersebut membentuk tepian mesh. Kemudian akan terbentuk sebuah topologi star berupa daerah poligon yang terdiri dari banyak segitiga yang memiliki satu vertex yang sama, yang disebut sebagai vertex pusat.

Dari sebuah objek tiga dimensi dapat dibentuk banyak topologi star, dari banyak topologi star ini akan dipilih beberapa edge untuk menjadi kandidat edge dengan syarat kandidat edge yang terpilih tidak boleh terhubung ke kandidat edge lain (Gambar 3). Dari kumpulan kandidat edge akan dibangkitkan edge-edge yang akan disisipi oleh watermark dengan menggunakan $\mathrm{PN}$ sequence.

Watermark yang telah diubah menjadi bit-bit biner disisipkan ke dalam vertex yang berbobot kecil dari edge kandidat dengan cara menambahkan bobot dengan nilai watermark-nya.

\subsection{PN Sequence $[1]$}

PN sequence adalah sebuah sekuensial bilangan-bilangan yang elemen-elemennya tidak akan berulang. Misalkan kita memiliki sebuah sekuensial sepanjang 9 bit, maka sekuensial tersebut akan mengandung 9 angka yang berbeda. Pada sistem watermarking ini, PN sequence dibangkitkan dari sebuah Generator PN untuk digunakan sebagai penentu kandidat edge yang disisipi oleh informasi watermark. pada proses membangkitkan PN sequence akan dibutuhkan sebuah kunci berupa bilangan yang hanya diketahui oleh si pembuat watermark.

\subsection{Serangan Geometri}

Serangan geometri diberikan kepada objek tiga dimensi yang telah disisipi watermark, hal ini bertujuan untuk mengetahui seberapa kuatkah watermark yang disisipkan ke dalam objek tiga dimensi. Apabila watermark dapat diekstrak dan dapat dikenali dengan baik setelah host objek tiga dimensi diberi serangan maka dapat dikatakan bahwa watermark kuat terhadap serangan. berikut adalah beberapa macam serangan geometri yang dapat dilakukan pada objek tiga dimensi:

a. Rotasi $[6,7]$

Rotasi adalah perputaran objek pada suatu sumbu tertentu dan sejauh sudut yang diinginkan.

b. Scaling [9]

Scaling adalah proses untuk mengubah ukuran objek menjadi lebih besar atau lebih kecil, tergantung pada skala pengalinya.

c. Translasi [8]

Translasi adalah proses pergeseran koordinat suatu objek, bisa terhadap sumbu dan jarak yang diinginkan.

d. Cropping

Cropping adalah proses menghilangkan suatu bagian dari objek tiga dimensi. Pada objek tiga 
dimensi cropping berarti menghilangkan beberapa face dan vertex.

\section{Desain dan Perancangan Sistem}

Pada bab ini dijelaskan tentang perancangan sistem, dimana prosesnya dibagi menjadi 2 tahap, yaitu tahap penanaman watermark dan tahap pengambilan watermark. Sistem ini dirancang dengan menggunakan metoda connected vertices clustering and star topology yang memanfaatkan domain spasial untuk setiap tahap prosesnya. Karena sistem bekerja pada domain spasial maka tidak dibutuhkan transformasi khusus dalam sistem ini.

Pada proses penyisipan diperlukan sebuah host berupa objek tiga dimensi dengan format *.obj file. Untuk watermark yang akan disisipkan adalah gambar dua dimensi yang akan ditambahkan pada vertex host. Sistem watermark yang dirancang ini bersifat non-blind sehingga diperlukan host aslinya untuk proses ekstraksi. Dalam proses ekstraksi, objek tiga dimensi yang telah disisipi watermark dikurangi dengan host asli untuk mendapatkan kembali informasi yang disisipkan.

\subsection{Proses Penanaman Watermark}

Pada proses penyisipan watermark, dibutuhkan sebuah host berupa objek tiga dimensi yang akan disisipi sebuah watermark berupa gambar dua dimensi. Sebelum disisipkan ke dalam host, watermark terlebih dahulu diubah menjadi gambar biner yang hanya mempunyai warna hitam dan putih. Dari watermark yang telah diubah menjadi gambar biner didapatkan bit biner 0 dan 1 lalu diberi bobot masing-masing dan ditambahkan ke dalam koordinat $X$ dari vertex terendah yang ada pada edge kandidat.

Dari host yang berupa objek tiga dimensi terlebih dahulu dicari vertex dan face-nya. Vertex adalah titik-titik koordinat yang ada pada sebuah objek tiga dimensi, sedangkan face adalah segitigasegitiga pembentuk permukaan objek tiga dimensi. Dari kumpulan face tersebut dapat dibentuk topologi star dengan cara mengumpulkan vertex-vertex dan face-face yang saling terhubung satu sama lain. Sebuah objek tiga dimensi dapat memiliki banyak topologi star yang saling terhubung. Kumpulan face dapat dikatakan sebagai sebuah topologi star apabila kumpulan face tersebut memiliki satu titik pusat yang sama.

Dari sebuah topologi star akan didapat daftar sisi-sisi atau edge penyusun topologi star. Edge penyusun topologi star ini diseleksi untuk menjadi kandidat edge dengan syarat setiap kandidat edge tidak boleh terhubung dengan kandidat edge lain. Hal ini bertujuan untuk mengurangi dampak pergeseran koordinat yang berantai yang disebabkan oleh bergesernya dua atau lebih edge karena penyisipan watermark pada satu vertex yang merupakan vertex bersama dari beberapa edge.
Dari sebuah edge kandidat dibangkitkan edgeedge yang akan disisipi informasi watermark. Edgeedge dibangkitkan sesuai dengan PN sequence yang dibangkitkan oleh Generator PN. Generator PN ini dibangkitkan dengan memasukkan sebuah kunci berupa bilangan yang hanya diketahui oleh si pemilik watermark. Edge yang telah dibangkitkan oleh PN sequence ini memiliki 2 vertex, vertex yang memiliki bobot lebih rendah disebut dengan vertex kandidat yang disisipi watermark. Bobot watermark akan ditambahkan pada elemen $X$ vertex kandidat dan berulang terus hingga semua bit watermark Disisipkan (Gambar 4).

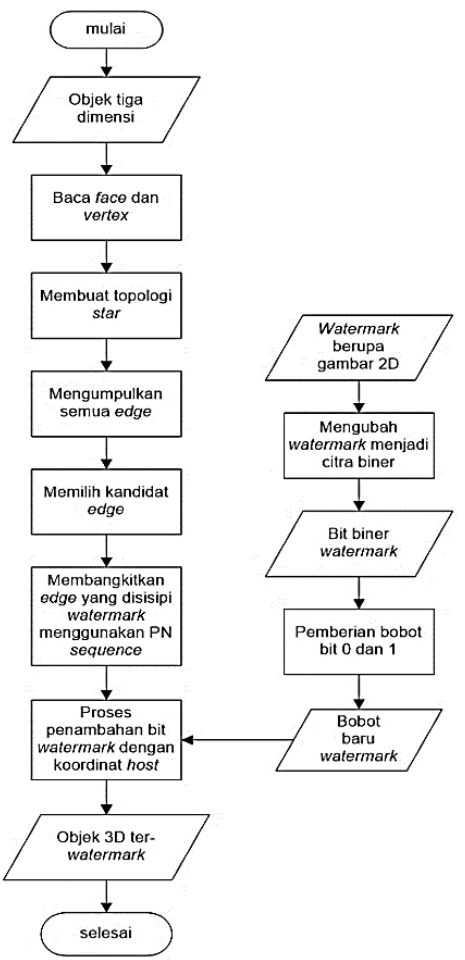

Gambar 4. Diagram Alir Proses Penyisipan

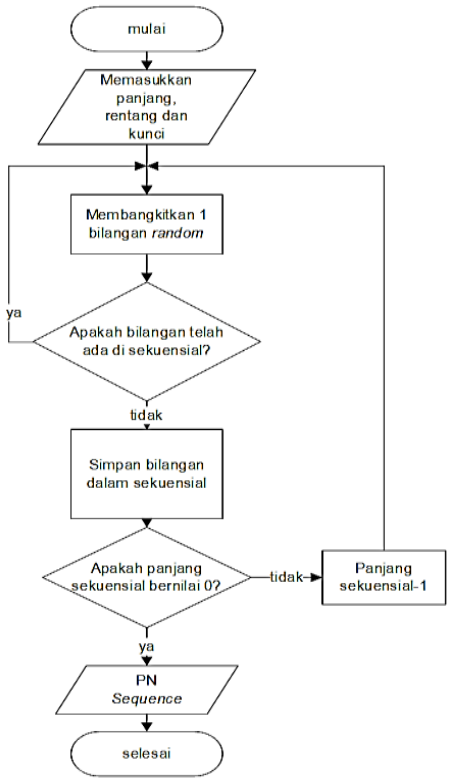

Gambar 5. Diagram Alir Generator PN 


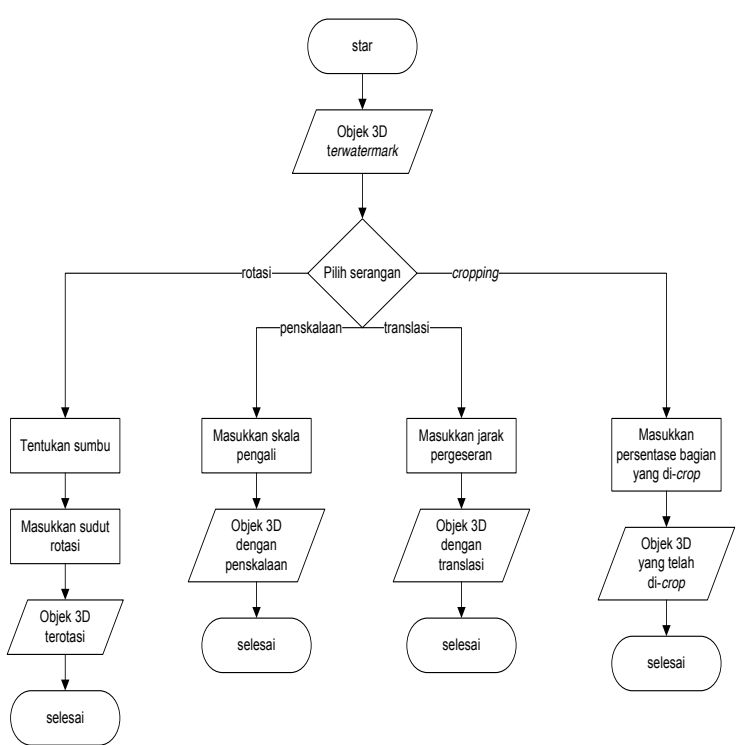

Gambar 6. Diagram Alir Proses Serangan

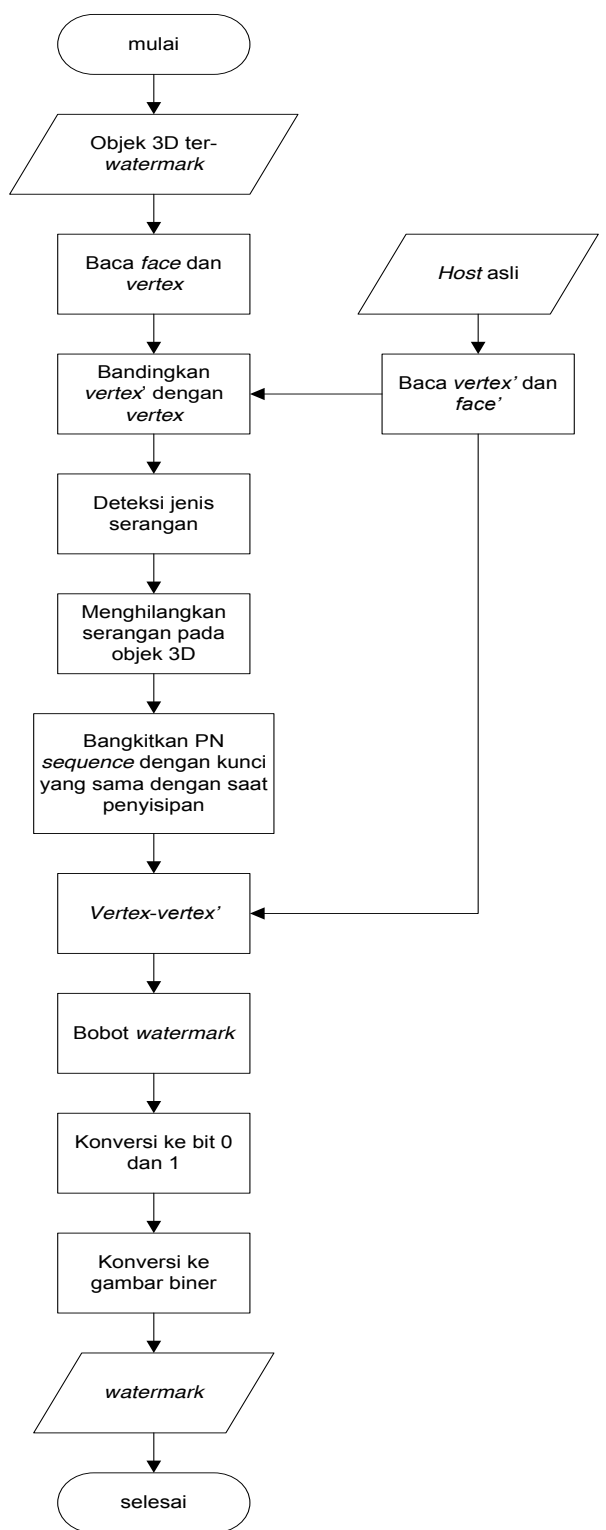

Gambar 7. Diagram Alir Proses Ekstraksi Watermark

\subsection{Proses Serangan}

Serangan dilakukan untuk menguji ketahanan dari watermark yang disisipkan. Adapun serangan yang dilakukan dalam sistem ini adalah serangan geometri berupa rotasi, translasi, scaling, cropping serta ditambahkan pula kombinasi serangan scaling dan translasi. Serangan dilakukan pada objek tiga dimensi yang telah disisipi oleh watermark untuk melihat apakah watermark masih dapat diekstrak dan dikenali dengan baik setelah dilakukan proses serangan pada host tiga dimensinya. Diagram alir proses serangan dapat dilihat pada Gambar 6.

\subsection{Proses Ekstraksi Watermark}

Proses ekstraksi watermark dilakukan dengan tujuan untuk mendapatkan informasi watermark yang disisipkan dari objek 3 dimensi yang telah disisipi watermark. Terdapat 2 proses ekstraksi dalam sistem ini, pertama ekstraksi untuk objek ter-watermark yang tidak diberi serangan dan yang kedua adalah proses ekstraksi untuk objek ter-watermark yang telah diberi serangan. Gambar 6 adalah diagram alir untuk mengekstraksi objek ter-watermark yang tidak diberi serangan.

Berdasarkan diagram alir di atas maka dapat dilihat bahwa untuk proses ekstraksi diperlukan host asli objek tiga dimensi untuk dikurangkan dengan objek tiga dimensi yang telah disisipi watermark. Selain itu juga perlu dibangkitkan PN sequence yang sama dengan PN sequence pada saat proses penyisipan watermark. PN sequence yang sama dapat dibangkitkan dengan cara memasukkan kunci yang sama dengan pada saat proses penyisipan. Kunci ini berupa sebuah bilangan yang hanya diketahui oleh si pembuat watermark. kemudian edge pada objek terwatermark akan dipilih lagi sesuai dengan PN sequence yang telah dibangkitkan untuk mendapatkan posisi penyisipan watermark.

Komponen $X$ dari posisi watermark pada objek ter-watermark dikurangi dengan nilai elemen $X$ dari host asli dan didapatkan bobot watermark-nya. Setelah mendapat nilai $W$, maka kita beri bobot 0 dan 1 untuk nilai-nilai $W^{\prime}$ tersebut. Setelah didapat bit biner maka dapat dikonversi bit-bit tersebut menjadi sebuah gambar biner dua dimensi yang merupakan informasi dari watermark yang telah disisipkan sebelumnya

\section{Pengujian Sistem dan Analisis Hasil}

Pengujian sistem dan analisis hasil pada penelitian ini adalah sebagai berikut.

\subsection{Skenario Pengujian}

Untuk mengetahui performansi sistem dilakukan pengujian pada proses penyisipan watermark, serangan, dan proses ekstraksi 
watermark. Dalam proses penyisipan watermark dibutuhkan beberapa objek tiga dimensi dengan format file *.obj dan dua gambar dua dimensi sebagai watermark. Tabel 1 menunjukkan objek-objek tiga dimensi yang menjadi host pada proses penyisipan. Sementara untuk watermark, yang disisipkan adalah berupa gambar dua dimensi yang menunjukkan identitas pemilik watermark (Tabel 2).

\subsection{Analisis Penyisipan Watermark Tanpa Serangan}

Pada skenario ini akan dilakukan penyisipan 2 watermark dengan ukuran yang sama ke dalam 4 host tiga dimensi. Tujuan dari skenario ini adalah untuk mengetahui sejauh mana performansi dari objek tiga dimensi setelah disisipi watermark dengan melihat parameter MSE, VER, dan SNR. Gambar 8 sampai dengan 10 menunjukkan grafik hasil pengujian.

Dari Gambar 8 dapat dijelaskan bahwa error yang terjadi pada objek tiga dimensi yang telah disisipi watermark sangat sedikit karena nilai MSEnya sangat kecil. Dari Gambar 9 dapat dijelaskan bahwa rasio perubahan vertex host tiga dimensi setelah disisipi watermark sangat kecil karena nilai VER-nya juga sangat kecil. Dari Gambar 10 dapat dijelaskan bahwa objek ter-watermark memiliki imperceptibility yang baik serta kecilnya nilai degradasi host tiga dimensi setelah disisipi watermark.

Dari ketiga grafik di atas dapat disimpulkan bahwa ukuran host mempengaruhi nilai MSE dan VER. Semakin besar ukuran host maka semakin kecil nilai MSE dan VER-nya. Hal ini terjadi karena semakin banyak vertex yang tidak disisipi watermark, sehingga tidak berubah nilai. Selain itu setelah disisipi watermark pun performansi objek tiga dimensi masih tetap bagus sehingga tujuan watermark ideal sudah terpenuhi, yaitu watermark yang disisipkan tidak menggangu fungsi dari host karena watermark tidak merusak tampilan host.

\subsection{Pengaruh Serangan Rotasi}

Sejauh berapa pun objek ter-watermark dirotasi, watermark yang disisipkan dapat diekstrak dengan sempurna oleh sistem. Hal ini berlaku untuk rotasi terhadap sumbu $X, Y$, dan $Z$ serta menghasilkan BER dengan nilai nol. Hal ini membuktikan bahwa sistem robust terhadap serangan rotasi.

Pada skenario ini dan skenario-skenario selanjutnya, parameter MSE, VER, dan SNR tidak akan dianalisis lebih jauh. Hal ini dikarenakan adanya serangan yang dilakukan terhadap domain spasial yang mengakibatkan kerusakan pada face dan vertex dari objek ter-watermark. Kerusakan face dan vertex pada objek ter-watermark akan menghasilkan nilainilai MSE, VER, dan SNR yang tidak ideal dan sangat beragam tergantung dari intensitas serangan yang diberikan.
Tabel 1. Tabel Host

\begin{tabular}{|c|c|c|c|c|}
\hline Nama & Gambar & Face & Vertex & Ukuran \\
\hline Boneka & & 7152 & 3980 & $232 \mathrm{~Kb}$ \\
\hline Perahu & & 11566 & 6127 & $\begin{array}{l}369 \\
\mathrm{~Kb}\end{array}$ \\
\hline Pesawat & & 7446 & 5303 & $\begin{array}{l}286 \\
\mathrm{~Kb}\end{array}$ \\
\hline Terompet & & 23696 & 12070 & $\begin{array}{l}816 \\
\mathrm{~Kb}\end{array}$ \\
\hline
\end{tabular}

Tabel 2. Tabel Watermark

\begin{tabular}{|c|c|c|}
\hline Nama & Gambar & Ukuran \\
\hline Nim.jpg & $\mathbf{1 1 1 0 9 0 0 4 9}$ & $\begin{array}{c}88 \times 13 \\
\text { piksel }\end{array}$ \\
\hline Nama.jpg & OriZaintani & $\begin{array}{c}88 \times 13 \\
\text { piksel }\end{array}$ \\
\hline
\end{tabular}

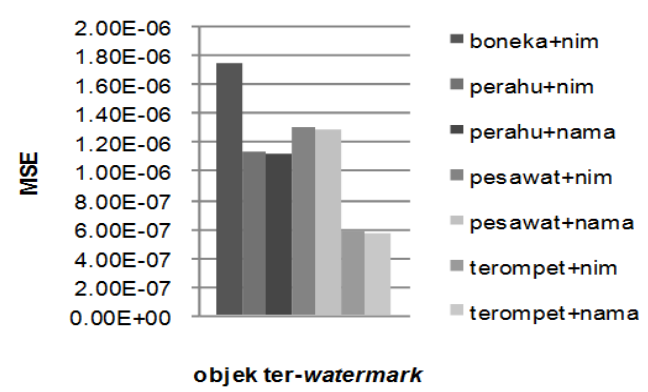

Gambar 8. Grafik MSE Objek Ter-watermark

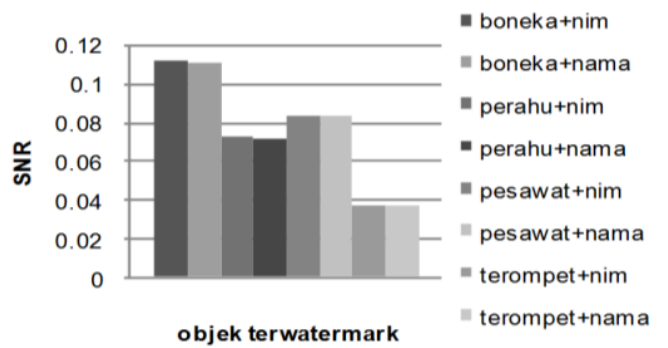

Gambar 9. Grafik VER Objek Ter-watermark

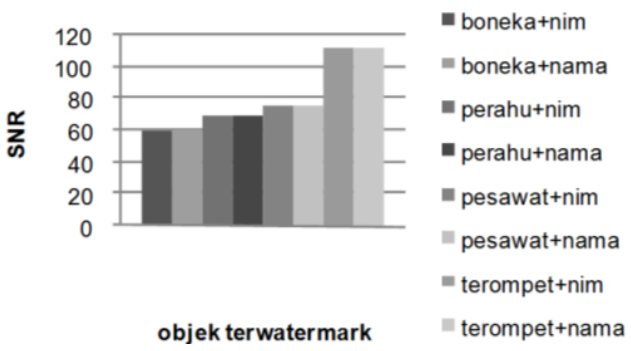

Gambar 10. Grafik SNR Objek Ter-watermark 


\subsection{Pengaruh Serangan Translasi Terhadap Parameter Performansi}

Sejauh berapa pun objek ter-watermark ditranslasi, watermark akan dapat diekstraksi dengan sempurna oleh sistem. BER watermark selalu bernilai 0 sehingga membuktikan bahwa sistem robust terhadap serangan translasi.

\subsection{Pengaruh Serangan Scaling Terhadap Parameter Performansi}

Berapa pun nilai skala, watermark akan dapat diekstrak dengan sempurna oleh sistem. BER watermark selalu bernilai 0 sehingga membuktikan bahwa sistem robust terhadap serangan scaling.

\subsection{Pengaruh Serangan Cropping Terhadap Parameter Performansi}

Watermark hasil ekstraksi memiliki nilai BER yang cukup besar, bahkan citra watermark sudah tidak dapat dikenali lagi. Untuk objek ter-watermark yang telah diberi serangan cropping dengan presentase crop diatas 0,1 tidak dapat diekstrak. Hal ini dikarenakan proses pencarian kandidat edge pada objek ter-watermark yang akan diekstraksi menghasilkan jumlah yang berbeda dengan pencarian kandidat $e d g e$ pada saat proses penyisipan. Perbedaan jumlah kandidat edge ini diakibatkan oleh banyaknya face dan vertex yang hilang.

\subsection{Pengaruh Serangan Invers Terhadap Parameter Performansi}

Setelah dilakukan serangan invers pada objek tiga dimensi yang telah disisipi watermark, watermark dapat diekstrak dengan sempurna oleh sistem. Hal ini terbukti dari parameter BER yang bernilai nol sehingga sekaligus membuktikan bahwa sistem robust terhadap serangan invers.

\subsection{Pengaruh Serangan Kombinasi Scaling dan Translasi Terhadap Parameter Performansi}

Dari pengujian ini didapatkan nilai BER nol yang berarti watermark dapat diekstrak dengan sempurna oleh sistem. Dari hasil pengujian ini dapat disimpulkan bahwa sistem robust terhadap kombinasi serangan scaling dan translasi.

\subsection{Pengaruh Serangan Kombinasi Scaling, Translasi dan Invers Terhadap Parameter Performansi}

Dari setiap pengujian yang dilakukan selalu didapatkan nilai BER nol yang berarti watermark dapat diekstrak dengan sempurna oleh sistem. Maka disimpulkan bahwa sistem robust terhadap kombinasi serangan scaling dan translasi.

\section{Kesimpulan}

Kesimpulan yang dapat diambil dari penelitian ini, antara lain:

a. Watermarking 3D yang dilakukan makalah ini menggunakan clustering terhadap vertex yang saling terhubung dan topologi star dalam skema penyisipannya.

b. Pada proses penyisipan didapatkan nilai MSE dan VER yang sangat kecil hingga mendekati nol, sedangkan nilai SNR-nya cukup besar. Nilai SNR terbesar ada pada host pesawat yang disisipi watermark nama dengan nilai SNR 111,831. Bila semakin kecil, nilai MSE dan VER maka nilai SNR akan semakin besar.

c. Ukuran host dapat mempengaruhi nilai MSE, VER, dan SNR. Semakin besar ukuran host maka nilai MSE dan VER semakin kecil dan nilai SNR semakin besar.

d. Setelah diberi serangan rotasi, nilai MSE dan VER menjadi sangat besar dan nilai SNR menjadi sangat kecil. Hal ini disebabkan karena serangan geometri merusak vertex dan face dari host. Namun semua watermark dapat diekstrak dengan baik oleh sistem dan menghasilkan BER dengan nilai 0 yang berarti tidak ada error pada watermark hasil ekstraksi dan sistem robust terhadap serangan rotasi.

e. Setelah diberi serangan translasi, nilai MSE dan VER menjadi sangat besar dan nilai MSE menjadi sangat kecil. Untuk BER watermark pada saat proses ekstraksi bernilai 0 yang berarti tidak ada error pada watermark hasil ekstraksi dan sistem robust terhadap serangan translasi.

f. Setelah diberi serangan scaling, nilai MSE dan VER menjadi sangat besar dan nilai SNR menjadi sangat kecil. Untuk BER watermark pada saat proses ekstraksi bernilai 0 yang berarti tidak ada error pada watermark hasil ekstraksi dan sistem robust terhadap serangan scaling.

g. Setelah diberi serangan cropping, nilai MSE dan VER menjadi besar dan nilai SNR menjadi kecil. Watermark hasil ekstraksi memiliki nilai BER yang sangat besar, bahkan watermark sudah tidak dapat dikenali lagi.

h. Setelah diberi serangan invers, nilai MSE dan VER menjadi sangat besar dan nilai MSE menjadi sangat kecil. Untuk BER watermark pada saat proses ekstraksi bernilai 0 yang berarti tidak ada error pada watermark hasil ekstraksi dan sistem robust terhadap serangan translasi.

i. Setelah dilakukan kombinasi serangan scaling dan translasi, nilai MSE dan VER menjadi sangat besar dan nilai SNR menjadi sangat kecil. Untuk BER watermark pada saat proses ekstraksi bernilai 0 yang berarti tidak ada error pada watermark hasil ekstraksi dan sistem robust terhadap kombinasi serangan scaling dan translasi. 
j. Setelah dilakukan kombinasi serangan scaling, translasi dan invers, nilai MSE dan VER menjadi sangat besar dan nilai SNR menjadi sangat kecil. Untuk BER watermark pada saat proses ekstraksi bernilai 0 yang berarti tidak ada error pada watermark hasil ekstraksi dan sistem robust terhadap kombinasi serangan scaling, translasi dan invers.

\section{Daftar Pustaka}

[1] “3D Mesh Topology Tip: Quads vs. Triangles", 2008, Diakses pada tanggal 9 Juni 2013 dari http://blendernewbies.blogspot.com/2008/11/3 d-mesh-topology-tip-quads-vs-triangles.html

[2] “3D Rotation", Diakses pada tanggal 29 April 2013 dari

http://www.siggraph.org/education/materials/ HyperGraph/modeling/mod tran/3drota.htm

[3] Aron, "Space and Matrix Transformations Building a 3D”, Diakses pada tanggal 30 April 2013 dari

http:/www.codeproject.com/Articles/42086/S pace-and-Matrix-Transformations-Building-a3D-Eng.

[4] Away, Gunaidi Abdia, "The Shortcut of Matlab Programming”, Informatika, Bandung, 2006.

[5] Breed, Gary, "Bit Error Rate: Fundamental Concepts and Measurement Issue”, High Frequency Electronics Copyright (C) 2003 Summit Technical Media, LLC, 2003.

[6] Caesarendra, Wahyu dan Mochammad Ariyanto, "Panduan Belajar Mandiri Matlab", Elex Media Komputindo, Jakarta, 2011.

[7] Chalil, Munawar, "Simulasi dan Analisis NonBlind Watermarking pada Objek Digital 3D Berbasis Transformasi Lazy Wavelet”, Tugas Akhir Sarjana pada Fakultas Elektro dan Komunikasi IT Telkom Bandung: tidak diterbitkan, 2013.

[8] Febrina, Rizka, "Simulasi dan Analisis Watermarking 3D dengan Metode Transformasi Wavelet dan dengan Metode Fuzzy Logic”, Tugas Akhir Sarjana pada Fakultas Elektro dan Komunikasi IT Telkom Bandung: tidak diterbitkan, 2013.

[9] Garcia, Emmanuel dan Jean-Luc Dugelay "Texture-Based Watermarking of 3-D Video Objects", IEEE Transactions On Circuits And Systems For Video Technology, vol. 13, no. 8, 2003.

[10] Gruber, Diana, "The Mathematics of the $3 D$ Rotation Matrix”, Diakses pada tanggal 29 April 2013 dari

http://www.fastgraph.com/makegames/3drotat ion/.

[11] Iman, Hatta Yanuar, "Implementasi Watermarking pada Objek 3 Dimensi dengan Transformasi Wavelet", Tugas Akhir Sarjana pada Fakultas Informatika IT Telkom Bandung: tidak diterbitkan, 2006.

[12] Jafilun, "Digital Watermarking Pada Domain Spasial Menggunakan Teknik "Least Significant Bit”, Seminar Nasional Sistem dan Informatika, 2006.

[13] Liu Chen-Chung dan Pei-Chung Chun, "A Robust Three-Dimensional Model Watermarking Algorithm Based on Connected Vertices Clustering and Star Topology", International Journal of Advanced Information Technologies (IJAIT), vol. 4, no.2, 2010.

[14] Shrivastava, Sakshi dan Siddhartha Choubey, "Secure Image Based Watermark for 3D Image", International Conference on Communication Systems and Network Technologies, 2011.

[15] Wang Yu-Ping dan Shi-Min Hu, "A New Watermarking Method for $3 D$ Models Based on Integral Invariants. Ieee Transactions On Visualization And Computer Graphics", vol. 15, no. 2, 2009.

[16] "Wavefront Obj File Format Summary", Diakses pada tanggal 29 April 2013 dari http://www.fileformat.info/format/wavefronto bj/egff.htm. 